\title{
EVALUATION OF EXPERIMENTAL CONDITIONS FOR QUANTIFICATION OF LT PRODUCED BY HUMAN DERIVED ENTEROTOXIGENIC ESCHERICHIA COLI STRAINS
}

\author{
Melissa Ang-Simões Lasaro ${ }^{1}$; Juliana Falcão Rodrigues ${ }^{1}$; Joaquim Cabrera-Crespo ${ }^{2}$; \\ Maria Elisabete Sbrogio-Almeida ${ }^{2}$; Marcio de Oliveira Lasaro ${ }^{1 \$}$; Luís Carlos Souza Ferreira ${ }^{1 *}$
}

${ }^{1}$ Departamento de Microbiologia, Instituto de Ciências Biomédicas, Universidade de São Paulo, São Paulo, SP, Brasil; ${ }^{2}$ Divisão de Desenvolvimento Tecnológico e Produção, Instituto Butantan, São Paulo, SP, Brasil

Submitted: November 18, 2006; Returned to authors for corrections: May 31, 2007; Approved: June 21, 2007.

\begin{abstract}
The heat-labile toxin (LT) is a key virulence-associated factor associated with the non-invasive secretory diarrhea caused by enterotoxigenic Escherichia coli (ETEC) strains either in humans or domestic animals. Several LT detection methods have been reported but quantification of the toxin produced by wild-type ETEC strains is usually performed by the GM1 ganglyoside enzyme-linked immunosorbent assay (GM1 ELISA). In this study we conducted the optimization of an alternative LT-quantification method, the antibody-capture ELISA (cELISA). Detailed analysis of the appropriate dilutions of capture and detecting LT-specific antibodies significantly improved the sensitivity of the method. Additionally, testing of different LT extraction techniques indicated that sonic disruption of the bacterial cells enhanced LT recovery yields, in contrast to the usual procedure based on addition of polymyxin B to the culture medium as well as extraction methods based on chloroform or Triton X-100. Moreover, the present data indicate that performance of the LT extraction method based on polymyxin B treatment can vary among wild ETEC strains.
\end{abstract}

Key words: heat-labile toxin, LT, ETEC, cELISA.

\section{INTRODUCTION}

The heat-labile (LT) and heat-stable (ST) enterotoxins represent virulence-associated traits of enterotoxigenic Escherichia coli strains infecting humans and mammal species such as pigs and cows (4). The type I LT and cholera toxin (CT), produced by Vibrio cholerae, belong to a family of structurally, immunologically and phylogenetically related multimeric enterotoxins composed of a single $88-\mathrm{kDa}$ A subunit, which is processed into the toxic ADP-rybosylating A1 subunit, and 5 receptor-binding B subunits (13). Upon secretion to the periplasm, LTB monomers spontaneously assemble into pentamers that, in the presence of LTA, assemble into stable holotoxins. The pentameric B subunit complex mediates the high-affinity binding to ganglyosides, especially GM1, as well as galactose-containing glycoproteins present on the surface of enterocytes and other host cells (3). Receptor binding is an obligatory step for toxin internalization and toxic activity into the cell (16).

Detection of LT-producing ETEC strains have been carried out by several methods including passive immune hemolysis of sheep erythrocytes (10), immuneprecipitation assays, as the Biken test (14) or the membrane-filter assay (26), detection of induced cellular morphology using in vitro cultured cell lines, as the Vero cell assay (25) or the Y1 adrenal cell assay (7), DNA hybridization assays (19) and latex agglutination tests (24). Nonetheless, quantification of LT production has been mainly performed with capture-based enzyme methods as the GM1enzyme-linked immunosorbent assay (GM1-ELISA) $(2,23)$ and the antibody-capture ELISA (cELISA) (8,30). Capture-based LT quantification methods are widely accepted since they are sensitive, specific, fast and simple to perform. The GM1-ELISA

*Corresponding Author. Mailing address: Departamento de Microbiologia, Universidade de São Paulo, Av. Prof. Lineu Prestes, 1374, Cidade Universitária, São Paulo, Brazil. Tel.: (11) 3091-7338 ou (11) 3091-7354. E-mail: lcsf@usp.br

§Present address: The Wistar Institute, Philadelphia, USA. 
takes for grant that LT produced by ETEC strains display similar affinity to the ganglyoside receptor, responsible for the toxin binding to the microtiter plate wells $(2,23)$. Similarly, cELISA relies on the specific recognition of surface-exposed epitopes by polyclonal or monoclonal anti-LT or anti-CT antibodies $(8,15,30)$. Both methods have been successfully used to detect LT production by different ETEC strains but only GM1-ELISA was previously evaluated in regard to factors that influence its sensitivity (5).

Another important parameter affecting detection of LT produced by ETEC strains is the toxin extraction method. Several LT-extraction procedures have been reported including the use of polymyxin B, Triton X-100, lincomycin, mitomycin C and sonic disruption, but the definition of the best approach based on a comparative quantitative analysis has not been performed $(5,8,20,23)$. In this study we evaluate two aspects concerning quantification of LT produced by ETEC strains: the experimental parameters affecting the optimal performance of a LT quantitative method (cELISA) and a comparison of different techniques employed for releasing LT produced by ETEC strains.

\section{MATERIALS AND METHODS}

\section{Bacterial strains and growth conditions}

The serotype and toxin profiles of the tested ETEC strains are depicted in Table 1. Seven ETEC strains were employed in the evaluation of different experimental parameters affecting LT quantification. Three LT-producing strains (1372-1, 4092-7, and 4692-5) were isolated from asymptomatic children, while three LT-producing ETEC strains (4811-1, 4101-1 and 2811-1) were recovered from diarrheic children living in Brazil $(12,22)$. The $\mathrm{LT}^{+} / \mathrm{ST}^{+}$ETEC $\mathrm{H} 10407$ strain, isolated from a patient with severe cholera-like disease in Bangladesh (9), was included as a reference strain. One non-toxinogenic derivative of the ETEC 4611-4 (O159: $\mathrm{H}_{\left.21 ~ \mathrm{LT}^{+}\right)}$strain, originally isolated from a diarrheic subject, was used a negative control for LT production. Cultures were routinely prepared in CAYE medium ( $2 \%$ Casamino acids, $0.6 \%$ yeast extract, $43 \mathrm{mM} \mathrm{NaCl}, 38 \mathrm{mM} \mathrm{K}_{2} \mathrm{HPO}_{4}, 0.1 \%$ trace salt solution consisting of $203 \mathrm{mM} \mathrm{MgSO}_{4}, 25 \mathrm{mM} \mathrm{MnCl}_{2}, 18$ $\left.\mathrm{mM} \mathrm{FeCl}{ }_{3}\right)$ (1) and incubated overnight $(18 \mathrm{~h})$ at $37^{\circ} \mathrm{C}$ with vigorous agitation (200 rpm in a rotary shaker).

\section{Isolation of LT-enriched fractions}

The same amount of bacterial cells, corresponding to 13-14 $\mathrm{A}_{600 \mathrm{~nm}}$, of each sample was centrifuged at 3,000 $\mathrm{x}$ g for $15 \mathrm{~min}$. LT-enriched fractions were obtained after suspension of bacterial pellets in $3 \mathrm{ml}$ of TE buffer ( $50 \mathrm{mM}$ Tris, $10 \mathrm{mM}$ EDTA) or PBS buffer ( $100 \mathrm{mM}$ phosphate, $150 \mathrm{mM} \mathrm{NaCl}, \mathrm{pH}$ 7.2) followed by different treatments to release the toxin from the bacterial cells, including (i) sonic disruption with a Branson sonifier 450D, (ii) incubation with $0.1 \%$ non-ionic detergent Triton X-100 (SigmaAldrich), or (iii) 2,000 $\mathrm{U} \mathrm{ml}^{-1}$ polymyxin B sulfate (Sigma-Aldrich), as previously described $(8,9)$. Moreover, the bacterial pellet was also submitted to treatment with chloroform, as reported by Ames and colleagues (1). Cell debris were removed by centrifugation at $5,000 \mathrm{x}$ g for $15 \mathrm{~min}$ at $4^{\circ} \mathrm{C}$ and supernatants, corresponding to cell-associated LT, assayed immediately or stored at $-20^{\circ} \mathrm{C}$ for up to 7 days.

\section{Purification of LT and generation of specific anti-CT and anti- LT sera}

A recombinant LT form, derived from the $\mathrm{H} 10407$ strain but expressed in E. coli $\mathrm{K} 12$, was purified according to previously described procedures (18). Similarly, generation of anti-CT and anti-LT sera following immunization of rabbits and mice, respectively, were carried as previously reported (18).

\section{Capture ELISA (cELISA)}

The cELISA was carried out as previously described by Drevet and Guinet (1991) with modifications as briefly described. The anti-CT rabbit serum was used as the capture reagent, while the anti-LT mouse serum was employed as the detecting antibody. Polystyrene 96-well titration plates (Nunc Maxisorp plates) were coated overnight at $4^{\circ} \mathrm{C}$ with $100 \mu \mathrm{l}$ aliquots of the anti-CT serum diluted in PBS containing 0.05\% Tween-20 (PBST). Plates were washed with PBS and blocked with PBST containing $5 \%(\mathrm{wt} / \mathrm{vol})$ skim milk for $1 \mathrm{~h}$ at $37^{\circ} \mathrm{C}$. Undiluted LT-enriched fractions samples were applied in duplicate wells and then serially 2-fold diluted in blocking solution. A titration curve was generated with purified recombinant LT. Plates were incubated for $2 \mathrm{~h}$, washed and incubated for $90 \mathrm{~min}$ at room temperature with mouse anti-LT serum diluted in blocking solution. After washing, horseradish peroxidase-conjugated goat antibody directed against mouse IgG (Sigma-Aldrich) and diluted in blocking solution $(1: 3,000)$, was added and incubated for $90 \mathrm{~min}$. After additional washes, the bound LT was detected with the chromogenic substrate, O-phenylene-diamine dihydrochloride $\left(1 \mathrm{mg} \mathrm{ml}^{-1}\right)$ (Sigma-Aldrich). After $20 \mathrm{~min}$ at room temperature the reactions were interrupted by addition of $1 \mathrm{M} \mathrm{H}_{2} \mathrm{SO}_{4}(50 \mu \mathrm{l}$ per well) and the reaction $\mathrm{A}_{492 \mathrm{~mm}}$ measured in an ELISA spectrophotometer (Multiscan MS- Labsystems). The final reaction values were obtained after deduction of background absorbance measured in control wells filled with cell extracts of the LT $^{-}$derivative of the 4611-4 strain. The tests were performed in duplicate samples repeated at least 3 times. The results were expressed as the means $\pm \mathrm{SD}$. The cut off values were determined as the mean $\mathrm{A}_{492 \mathrm{~nm}}$ of the negative control plus 3-fold the SD. Linear regression analysis $\left(R^{2}>0.97\right)$ was used to generate a standard curve with LT purified from the H10407 strain.

\section{GM1-ELISA}

The GM1-ELISA was carried out as previously described (23). In short, wells of polystyrene 96-well microtiter plate (Nalge Nunc Polysorp) were coated with PBS-diluted GM1 ganglyoside 
$\left(2 \mu \mathrm{g} \mathrm{ml}^{-1}\right)$ (Sigma-Aldrich) and incubated overnight at room temperature. In the next day plates were washed, blocked with a $0.1 \%$ BSA in PBS for $30 \mathrm{~min}$ at $37^{\circ} \mathrm{C}$ and washed again. Undiluted bacterial extracts were dispensed in duplicate wells and then 2fold serially diluted. All subsequent steps were identical to cELISA procedure.

\section{Statistical evaluations}

Statistical analyses were carried out with the Student's test and $P$ values $<0.05$ were taken as indicative of statistical significance.

\section{RESULTS}

In our hands the cELISA showed a consistently lower sensitivity than GM1-ELISA when used for the quantification of LT produced by human-derived ETEC strains. Nonetheless, the performance of the cELISA could be significantly improved following optimization of the capturing (rabbit anti-CT serum) and detection (mouse anti-LT serum) antibody dilutions employed in the quantification method. Maximal sensitivity of the cELISA was achieved when the anti-CT and anti-LT sera were diluted 1,000 and 500 fold, respectively (Fig. 1). Under optimal assay conditions the detection limits of cELISA and GM1-ELISA were 2 and $0.5 \mathrm{ng}$ of purified LT, respectively. Using both methods, LT concentrations ranging from 2 to approximately $30 \mathrm{ng} \mathrm{ml}^{-1}$ fit into the linear portion of the standard curves. These standard curves were used to determine the LT concentrations produced by different LT-producing ETEC strains (Fig. 2).

Determination of LT produced by different ETEC strains usually requires a cell permeabilization step with polymyxin B, which contributes to the release of the toxin retained in the periplasm into the growth medium $(11,23,27)$. To ensure that the maximal amount of LT produced by the different ETEC strains could be detected, we compared different permeabilization treatments, including incubation with polymyxin B, Triton X100 , chloroform or sonic disruption using as a reference the H10407 strain. As indicated in Figure 3, maximal LT levels were detected in whole cells extracts submitted to the sonic treatment. The amount of LT recovered after polymyxin B treatment corresponded to approximately $25 \%$ of the total LT measured in whole cell extracts. Incubation of the bacterial cells with Triton X-100 and chloroform recovered less than $15 \%$ of the toxin produced by the bacterial cells (Fig. 3).

Based on the optimized experimental conditions allowing quantification of LT by the cELISA, three additional wild $\mathrm{LT}^{+}$ ETEC strains isolated from asymptomatic children (1372-1, 4092$7,4692-5)$ and three strains recovered from diarrheic children (4811-1, 4101-1 and 2811-1) were tested for production of LT following extraction with polymyxin B or sonic disruption. The amount of LT produced by the ETEC strains ranged from 25 to
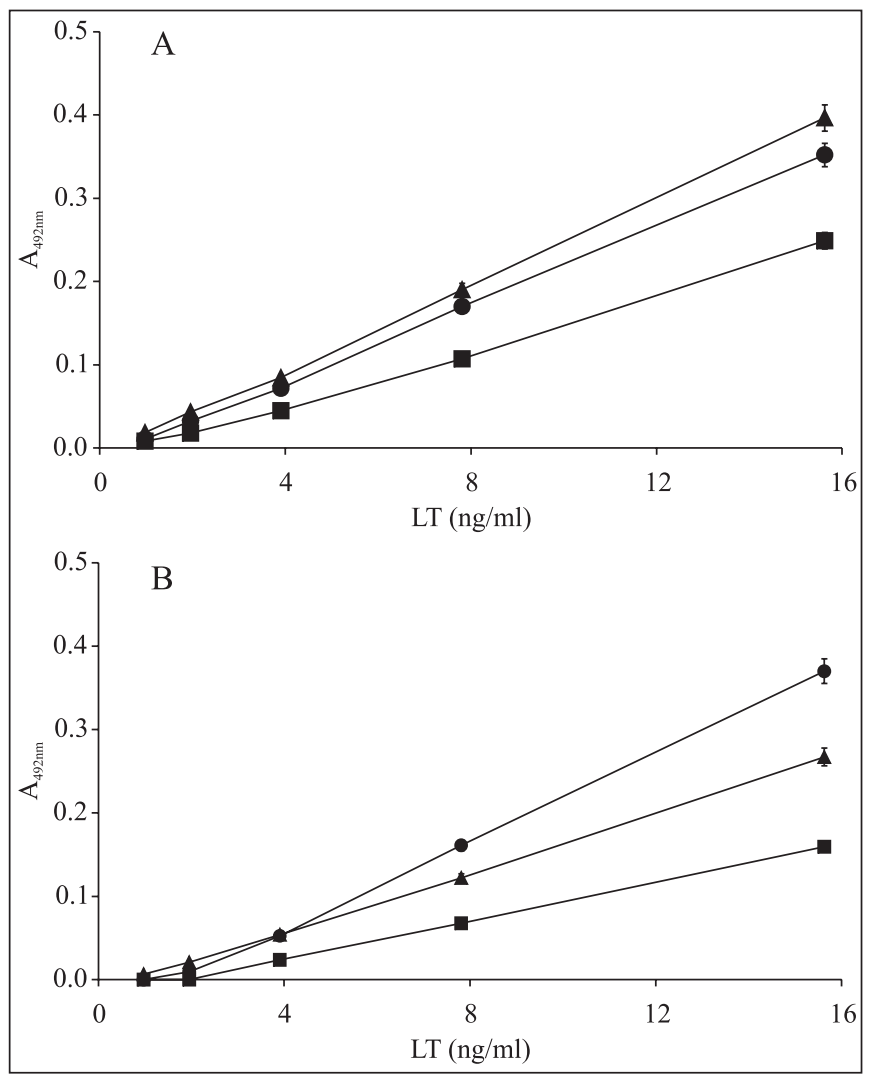

Figure 1. Optimization of the LT quantification conditions using the cELISA. (A) Titration curves of purified LT carried out with different dilutions of the rabbit anti-CT capture antibody. The anti-CT serum was diluted to 1:1,000 ( $\mathbf{\Delta}), 1: 2,000(\bullet)$ and 1:3,000 (ם) with PBST. A fixed dilution $(1: 5,000)$ of the detection antiLT serum was used in these tests. (B) Titration curves of purified LT carried out with different dilutions of the mouse anti-LT detection antibody. The anti-LT serum was diluted to 1:500 ( $)$, 1:5,000 ( $\mathbf{\Delta})$, and 1:10,000 ( $\mathbf{\square})$. A fixed dilution $(1: 1,000)$ of the capture anti-CT serum was employed in these tests. The capture anti-CT and detection anti-LT serum had anti-LT titers of $3 \mathrm{x}$ $10^{5}$ and $10^{5}$, respectively, as determined with GM1-ELISA. Data corresponding to two independent determinations are presented as the means of $\mathrm{A}_{492 \mathrm{~nm}}$.

$1,504 \mathrm{ng} \mathrm{ml}^{-1}$, following extraction by polymyxin $\mathrm{B}$, and from 57.4 to $2,028 \mathrm{ng} \mathrm{ml}^{-1}$, following sonic disruption of the cells (Table 1). The amount of LT extracted from ETEC strains treated with polymyxin B varied from 4.8 , in the $1372-1$ strain, to $74 \%$, in the 2811-1 strain, of the total LT detected in sonic extracts of the corresponding tested strain (Table 1). The optimized quantification method has been established in our routine laboratory practices and successfully used in the determination of LT produced by wild type ETEC isolates (18 and data not shown). 
Table 1. Quantification of LT produced by wild type ETEC strains.

\begin{tabular}{ccccccc}
\hline \multirow{2}{*}{ Strain } & \multirow{2}{*}{ Serotype $^{\mathrm{a}}$} & Source $^{\mathrm{b}}$ & $\operatorname{Toxin}^{\mathrm{c}}$ & \multicolumn{2}{c}{ Cell LT $\left.(\mathrm{ng} \mathrm{ml})^{-1}\right)^{\mathrm{d}}$} & \multirow{2}{*}{${\text { Extraction Efficiency }(\%)^{\mathrm{e}}}$} \\
\cline { 5 - 6 } & & & & Polymyxin B & Sonication & \\
\hline $1372-1$ & O23:H28 & AC & LT & $36.0 \pm 9.3$ & $746.7 \pm 28.0$ & 4.8 \\
$4092-7$ & ND:H21 & AC & LT & $538.7 \pm 227.8$ & $1,097.2 \pm 8.7$ & 49.0 \\
$4692-5$ & ND:H & AC & LT & $60.5 \pm 8.3$ & $481.6 \pm 51.9$ & 12.6 \\
$4811-1$ & O9:H21 & DC & LT & $25.0 \pm 1.5$ & $57.4 \pm 1.8$ & 43.5 \\
$4101-1$ & O114:H & DC & LT & $285.2 \pm 176.8$ & $1,517.5 \pm 298.8$ & 18.8 \\
$2811-1$ & O88:H25 & DC & LT & $1,504.0 \pm 215.7$ & $2,028.2 \pm 269.9$ & 74.0 \\
H10407 & O78:H11 & DC & LT/ST & $377.0 \pm 11.7$ & $513.3 \pm 42.9$ & 73.4 \\
\hline
\end{tabular}

${ }^{\text {a }} \mathrm{ND}$, not determined; ${ }^{\mathrm{b}} \mathrm{AC}$, isolated from an asymptomatic child; DC, isolated from a diarrheic child; ${ }^{\mathrm{c}} \mathrm{LT}$, LT only producing strains; LT/ST, LT and ST producing strain; ${ }^{\mathrm{d}}$ LT detected in ETEC cultures following treatment with polymyxin B or sonic disruption of the cells. Values expressed by means \pm SD of three independent experiments; ${ }^{\mathrm{e}}$ Polymyxin B extraction efficiency expressed as the ratio of LT detected in extracts obtained following polymyxin B treatment/total LT detected in sonic extracts x 100.

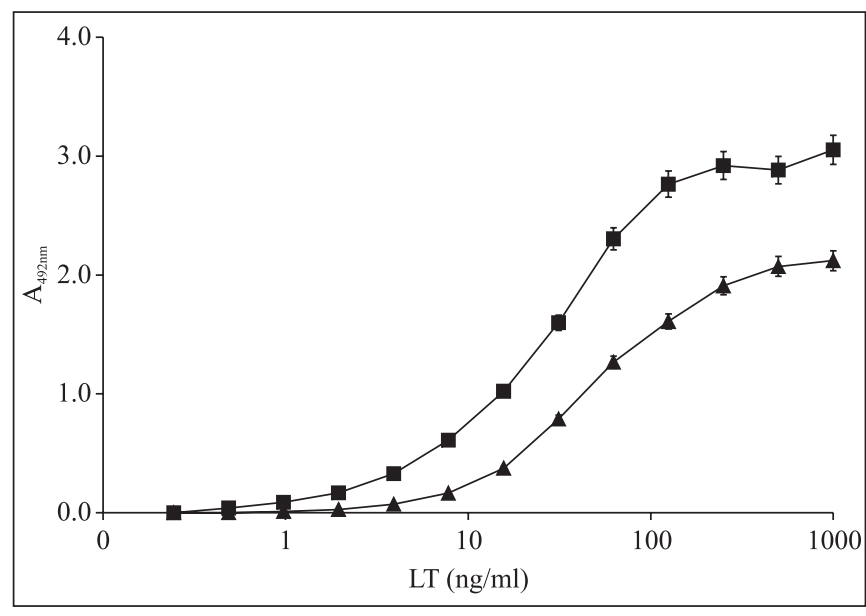

Figure 2. Titration curves of purified LT. Standard curves were determined with LT purified from the H10407 strain using the GM1-ELISA $(\square)$ or cELISA ( $\mathbf{\Delta})$. GM1-ELISA was performed as described in the text. cELISA was carried out with the anti-CT capture antibody (final dilution of 1:1,000) and anti-LT detection antibody (final dilution of 1:500). Data corresponding two independent determinations are presented as the means of $\mathrm{A}_{492 \mathrm{~nm}}$. Detection limits for GM1-ELISA and cELISA were 0.5 and $2 \mathrm{ng}$ of LT, respectively. A cut off value of 0.03 at $\mathrm{A}_{492 \mathrm{~nm}}$ was adopted for both methods.

\section{DISCUSSION}

The cELISA method has been initially developed as a rather simple and rapid approach to detect and quantify LT produced by different ETEC strains using anti-CT or anti-LT antibodies $(8,15,30)$. Similarly, the GM1-ELISA has been the method of choice for the detection and quantification of LT expressed by

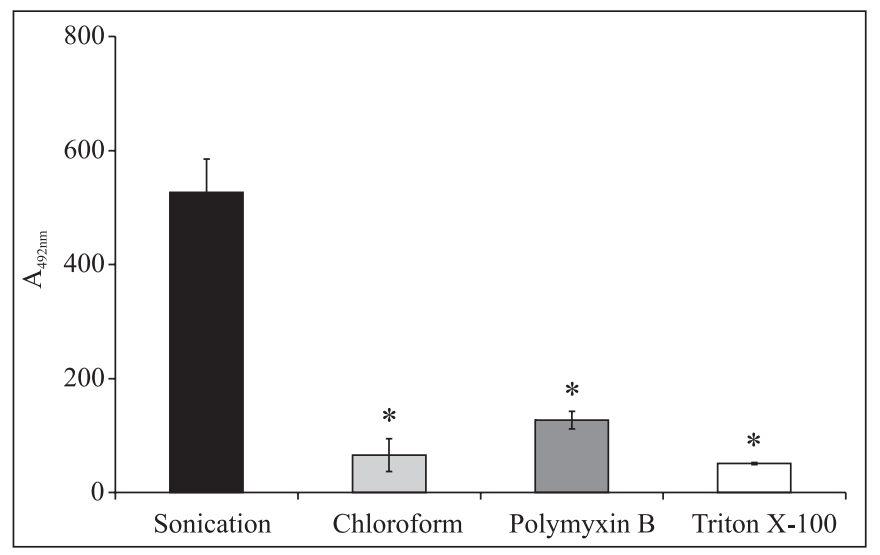

Figure 3. LT recovery yields following treatment of ETEC cells with different procedures. Aliquots of the ETEC H10407 strain containing the same amount of bacterial cells cultivated under identical growth conditions were submitted to sonic disruption (black bar), treatment with chloroform (light gray bar), polymyxin B (dark gray bar) or Triton X-100 (open bar). Quantification of the total LT in whole cell extracts or culture supernatants were carried out with cELISA under optimized assay conditions. Data corresponding to two independent determinations are presented as the means $\pm \mathrm{SD}$ of the $\mathrm{A}_{492 \mathrm{~nm}}$ * Statistically different values $(p<0.005)$ as compared to the sonic extract results.

ETEC strains based on the specificity of receptor-binding interaction $(2,23)$. In this study the sensitivity of the cELISA has been significantly improved following the establishment of appropriate dilutions of both capturing and detecting antibodies. Under optimized conditions, the cELISA resulted in reproducible quantitative results, either with purified protein or whole bacterial extracts. Linear quantification curves were 
obtained with LT concentrations ranging from 2 to $30 \mathrm{ng} \mathrm{ml}^{-1}$. However, minimum LT-specific serum titers of $10^{5}$ were required for the precise quantification of LT but no significant difference was noted following use of CT- or LT-specific sera as the capture or detecting reagents.

In contrast to CT produced by $V$. cholerae strains, LT is mainly accumulated in the periplasm and requires exposure of the bacterial cells to permeabilization treatments allowing release of the toxin into the medium. The quantification of the LT produced by the H10407 strain following exposure to different permeabilization treatments indicated that sonic disruption is the most efficient LT-releasing procedure. Although the standard GM1-ELISALT quantification method relies on the treatment of ETEC cultures with polymyxin B, our results indicated that roughly only $25 \%$ of the LT produced by the H10407 strain is recovered under ordinary conditions. Moreover, our results demonstrated that release of LT following polymyxin B treatment can significantly change according to the tested strain. In fact, polymyxin $\mathrm{B}$ resistance can reduce binding to the outer membrane lipopolysaccharide and release of the periplasmic content $(6,21)$. Thus, although use of polymyxin B did not affect qualitative screening of LT production by wild-type LT ETEC strains it may lead to underestimation of the total LT secreted by specific ETEC strains.

Production and release of LT can drastically vary among wild type ETEC strains (18). Based on the presently described LTquantification we determined that production of LT among 26 wild-type LT producing ETEC strains ranged from a minimum of $49.8 \mathrm{ng} / \mathrm{ml}$ to more than $2,400 \mathrm{ng} / \mathrm{ml}$ (18). Similarly, the amount of LT spontaneously released in culture supernatant of wild ETEC cultures varied from non detectable levels to approximately 250 ng, representing up to $50 \%$ of the total synthesized toxin (18). Besides the natural variability of LT expression by wild type strains, the present results indicate that specific ETEC strains may respond differently to the polymyxin B treatment. Although the present study did not aim the evaluation of the polymyxin B treatment in a larger number of ETEC strain, the present results clearly show that application of this LT-releasing procedure shall be carefully considered for those interested in the quantification of secreted LT levels. Moreover, the present results open up interesting perspectives regarding the possible correlation between serotypes, as well as other molecular or cellular features, and the release of LT following polymyxin B treatment.

\section{ACKNOWLEDGMENTS}

We thankfully acknowledge the contribution of Dr. B. E. Guth (Federal University of São Paulo) Dr. A. H. Régua-Mangia (Oswaldo Cruz Foundation) and Dr. A.M. Svennerholm (Göteborg University) for supplying the ETEC strains used in the present work. This work was supported by FAPESP and CNPq grants.

\section{RESUMO}

\section{Avaliação das condições experimentais para quantificação de LT produzida por linhagens de Escherichia coli enterotoxigênica isolada de humanos}

A toxina termo-lábil (LT) é um fator de virulência associado à diarréia secretora não invasiva causada por linhagens de Escherichia coli enterotoxigênica (ETEC) em humanos ou animais domésticos. Diversos métodos de detecção de LT foram descritos na literatura, no entanto, a quantificação da toxina produzida por linhagens selvagens de ETEC é geralmente realizada por ensaio imunoenzimático com o gangliosídeo GM1 (GM-1 ELISA). Neste estudo, conduzimos uma otimização experimental de um método alternativo de quantificação de LT, o ELISA de captura (cELISA). Análise detalhada de diluições apropriadas dos anticorpos LT específicos de captura e detecção melhorou significantemente a sensibilidade do método. Em adição, testes com diferentes técnicas de extração de LT indicaram que a ruptura das células por ultra-som, mas não o tratamento com polimixina B, clorofórmio ou Triton X-100, aumentou o rendimento da recuperação de LT. Além disto, os dados apresentados demonstram que o desempenho do método de extração de LT baseado no tratamento com polimixina B pode variar entre linhagens selvagens de ETEC.

Palavras-chave: toxina termo-lábil, LT, ETEC, cELISA.

\section{REFERENCES}

1. Ames, G.F.L.; Prody, C.; Kustu, S. (1984). Simple, rapid, and quantitative release of periplasmic proteins by chlorophorm. $J$. Bacteriol., 160, 1181-1183.

2. Bäck, E.; Svennerholm, A.M.; Holmgren, J.; Molby, R. (1979). Evaluation of a ganglyoside immunosorbent assay for detection of Escherichia coli heat-labile enterotoxin. J. Clin. Microbiol., 10, 791-795.

3. Bäckström, M.; Shahabi, V.; Johansson, S.; Teneberg, A.; Kjellberg, A.; Podraza, H.M.; Holmgren, J.; Lebens, M. (1997). Structural basis for differential receptor binding of cholera and Escherichia coli heat-labile toxins: influence of heterologous amino acid substitutions in the cholera B-subunit. Mol. Microbiol., 24, 489-497.

4. Black, R.E. (1990). Epidemiology of traveller's diarrhea and relative importance of various pathogens. Rev. Infec. Dis., 12S, 73-79.

5. Bongaerts, G.P.A.; Bruggeman-Ogle, K.M.; Mouton, R.P. (1985). Improvements in the microtitre GM1 ganglyoside enzyme-linked immunosorbent assay for Escherichia coli heat-labile enterotoxin. J. Appl. Bacteriol., 59, 443-449.

6. Daugelavièius, R.; Bakiene, E.; Bamford, D.H. (2000). Stages of polymyxin B interaction with the Escherichia coli cell envelope. Antimicrob. Agents Chemoth., 44, 2969-2978.

7. Donta, S.T.; Moon, H.W.; Whipp, S.C. (1974). Detection of heatlabile Escherichia coli enterotoxin with the use of adrenal cells in tissue culture. Science, 183, 334-336.

8. Drevet, P.; Guinet, R. (1991). Comparison of sandwich-ELISA and GM1-ELISA for the detection of Escherichia coli thermolabile enterotoxin. J. Imunoassay, 12, 293-304. 
9. Evans, D.G.; Silver, R.P.; Evans, D.J.Jr.; Chase, D.G.; Gorbach, S.L. (1975). Plasmid-controlled colonization factor associated with virulence in Escherichia coli enterotoxigenic for humans. Infec. Immun., 12, 656-667.

10. Evans, D.J.Jr.; Evans, D.G. (1977). Direct serological assay for the heat-labile enterotoxin of Escherichia coli, using passive hemolyis. Infect. Immun., 16, 604-609.

11. Evans, D.J.Jr.; Evans, D.G.; Richardson, S.H.; Gorbacj, S.L. (1974). Polymyxin B-induced release of low-molecular-weight, heat-labile enterotoxin from Escherichia coli. Infect. Immun., 10, 1010-1017.

12. Guth, B.E.C.; Aguiar, E.G.; Griffin, P.M.; Ramos, S.R.T.S.; Gomes, T.A.T. (1994). Prevalence of colonization factor antigens (CFAs) and adherence to HeLa cells in enterotoxigenic Escherichia coli isolated from feces of children in São Paulo. Microbiol. Immunol., 38, 695-701.

13. Hirst, T.H. Cholera toxin and Escherichia coli heat-labile enterotoxin. In: Alouf, J.E., Freer, J.H. (eds). (1999). The Comprehensive Sourcebook of Bacterial Protein Toxins. Academic Press, London, p.104-129.

14. Honda, T.; Taga, S.; Takeda, Y.; Miwatani, T.W. (1981). Modified Elek test for detection of heat-labile enterotoxin of enterotoxigenic Escherichia coli. J. Clin. Microbiol., 13, 1-5.

15. Honda, T.; Sato, M.; Miwatani, T. (1984). Differential detection of cholera enterotoxin and Escherichia coli heat-labile enterotoxin by enzyme-linked immunosorbent assays with antibodies specific to the two toxins. J. Clin. Microbiol., 20, 664-667.

16. Jobling, M.G.; Holmes, R.K. (1991). Analysis of structure and function of the B subunit of cholera toxin by the use of site-directed mutagenesis. Mol. Microbiol., 5, 1755-1767.

17. Kunkel, S.L.; Robertson, D.C. (1979). Factors affecting release of heat-labile enterotoxin by enterotoxigenic Escherichia coli. Infect. Immun., 23, 652-659.

18. Lasaro, M.A.S.; Rodrigues, J.F.; Mathias-Santos, C.; Guth, B.E.C.; Régua-Mangia, A.; Ferreira, A.J.P.; Tagaki, M.; Cabrera-Crespo, J.; Sbrogio-Almeida, M.E.; Ferreira, L.C.S. (2006). Production and release of heat-labile toxin by wild-type human-derived enterotoxigenic Escherichia coli. FEMS Immunol. Med. Microbiol., 48, 123-131.

19. Moseley, S.L.; Huq, I.; Alim, A.R.M.A.; So, M.; Samadpour-Motalebi, M.; Falkow, S. (1980). Detection of enterotoxigenic Escherichia coli by DNA colony hybridization. J. Infect. Dis., 142, 892-895.

20. Mundell, D.H.; Anselmo, C.R.; Wishnow, R.M. (1976). Factors influencing heat-labile Escherichia coli enterotoxin activity. Infect. Immun., 14, 383-388.

21. Nummila, K.; Kilpelainen, I.; Zahringer, U.; Vaara, M.; Helander I.M. (1995). Lipopolysaccharides of polymyxin B-resistant mutants of Escherichia coli are extensively substituted by 2 -aminoethyl pyrophosphate and contain aminoarabinose in lipid A. Mol. Microbiol., 16, 271-278.

22. Régua-Mangia, A.H.; Guth, B.C.; Andrade, J.R.C.; Irino, K.; Pacheco, A.B.F.; Ferreira, L.C.S.; Zahner, V.; Teixeira L.M. (2004). Genotypic and phenotypic characterization of enterotoxigenic Escherichia coli (ETEC) strains isolated in Rio de Janeiro city, Brazil. FEMS Immunol. Med. Microbiol., 40, 155-162.

23. Ristaino, P.A.; Levine, M.M.; Young, C.R. (1983). Improved GM1-enzyme-linked immunosorbent assay for detection of Escherichia coli heat-labile enterotoxin. J. Clin. Microbiol., 18, 808-815.

24. Scotland, S.M.; Flomen, R.H.; Rowe, B. (1989). Evaluation of a reversed passive latex agglutination test for the detection of Escherichia coli heat-labile toxin in culture supernatants. J. Clin. Microbiol., 27, 339-340.

25. Spiers, J.I.; Stavric, S.; Konowalchuk, J. (1977). Assay of Escherichia coli heat-labile enterotoxin with Vero cells. Infect. Immun., 16, 617-622.

26. Vadilevu, J.; Loyd, B.J.; Drasar, B.S.; Feachem, R.G.; Cox, N.P.; Harrison, T. J. (1986). Membrane filter assay for detection of enterotoxigenic Escherichia coli in epidemiological studies. Lancet, 1, 1007-1009.

27. Yolken, R.H.; Greenberg, H.B.; Merson, M.H.; Sack, R.B.; Kapikian, A.Z. (1977). Enzyme-linked immunosorbent assay for detection of Escherichia coli heat-labile enterotoxin. J. Clin. Microbiol., 6, 439444. 